\title{
SOLAR SOFTWARE APPLIED TO DESIGN A PHOTOVOLTAIC SYSTEM TO SUPPLY THE ENERGY DEMAND OF AN ITALIAN SCHOOL
}

\author{
P. Laranci ${ }^{\mathrm{a}}$, \\ J. L. Silveira ${ }^{b}$, \\ and W. Q. Lamas ${ }^{b}$ \\ ${ }^{a}$ Università degli Studi di Perugia \\ Dipartimento di Ingegneria Industriale \\ DII UNIPG \\ Via Duranti 67 \\ 06125 Perugia, Italia \\ paolo.laranci@unipg.it \\ ${ }^{\text {b}}$ Universidade Estadual Paulista \\ ABSTRACT \\ This paper has as objective to describe the use of SOLAR 1.1 software to \\ design a system for supplying a part of the electric demand of a school \\ situated in Umbertide, comparing the use o SOLAR 1.1 to real results of a \\ system implanted yet. This software version helps also to conduce the \\ economic analysis for grid connected or standalone photovoltaic systems \\ for the choice of convenient values of investment rate and annuity factor \\ and it calculates the payback period of investment in the photovoltaic plant. \\ Keywords: economic analysis, photovoltaic cell, photovoltaic systems, \\ solar radiation. \\ Faculdade de Engenharia \\ Departamento de Energia \\ Av. Dr. Ariberto Pereira da Cunha, 333 \\ 12516-410, Guaratinguetá, São Paulo, Brasil \\ \{joseluz,wendell\}@feg.unesp.br
}

\section{NOMENCLATURE}

\section{A PV panel surface, $\mathrm{m}^{2}$}

$\mathrm{C}_{\mathrm{b}} \quad$ cost of battery, US\$

$\mathrm{C}_{\mathrm{d}} \quad$ cost of acquisition and installation of

peripheral components, US\$

$\mathrm{C}_{\mathrm{el}} \quad$ cost of electric energy production in the photovoltaic system, US\$/kWh

$\mathrm{C}_{\mathrm{el}} \quad$ cost of electricity production in the PV system, US\$/kWh

$\mathrm{C}_{\mathrm{m}} \quad$ cost of a photovoltaic module, US\$

$\mathrm{C}_{\mathrm{ma}} \quad$ maintenance cost, US\$/kWh

$\mathrm{C}_{\operatorname{mex}} \quad$ marginal cost of expansion of the electric energy offer, US $\$ \mathrm{kWh}$

$\mathrm{C}_{\mathrm{op}} \quad$ operation costs, US $\$ \mathrm{kWh}$

E daily demand energy, Wh/day

$\mathrm{E}_{\mathrm{p}} \quad$ produced energy in a year, $\mathrm{kWh} /$ year

$\mathrm{F}$ annuity factor, year ${ }^{-1}$

$\mathrm{H}_{\mathrm{i}} \quad$ number of daily operation of the i-load,

h/day

$\mathrm{I}_{\mathrm{pl}} \quad$ total investment in the plant, US\$

$\mathrm{K}$ amortisation period, years

$n_{i} \quad$ number of the i-load

$\mathrm{n}_{\mathrm{m}} \quad$ number of module in the PV system

$\mathrm{n}_{\mathrm{w}} \quad$ number of working months, generally 13

$\mathrm{n}_{\mathrm{tec}}$ number of technicians needed for the operation

$\mathrm{P}_{\mathrm{el}} \quad$ electric tax, US $\$ / \mathrm{kWh}$

$\mathrm{P}_{\mathrm{i}} \quad$ power of the $\mathrm{i}-$ load, $\mathrm{W}$

$\mathrm{P}_{\mathrm{p}} \quad$ peak power, $\mathrm{W}_{\mathrm{p}}$
$\mathrm{R} \quad$ annual mean daily insolation, $\mathrm{Wh} / \mathrm{m}^{2}$.day

$\mathrm{R}$ annual interest rate, \%

$\mathrm{R}_{\mathrm{A}} \quad$ annual insolation, $\mathrm{kWh} / \mathrm{m}^{2}$.year

$\mathrm{S}_{\mathrm{al}}$ monthly salary of a technicians, US\$/month

$\mathrm{S}_{\mathrm{e}} \quad$ expected annual saving, US\$/year

$S_{\mathrm{ub}}$ governmental subsidy rate for the installation, \%

\section{Greek symbols}

$\begin{array}{ll}\eta & \text { panel efficiency, } \% \\ \eta_{\mathrm{M}} & \text { module efficiency, } \%\end{array}$

\section{INTRODUCTION}

Solar energy is largely used to produce heat and electricity around the world, where the photovoltaic (PV) technology allows transforming it in electric energy and the photothermal (PT) technology, in heat (NREL, 2009).

Particularly, photovoltaic energy represents an opportunity to produce electricity in the worldwide, mainly in the development countries, in those there are places where electricity grids are unreliable or non-existent and is inconvenient to make investments in a grid expansion. In far places often photovoltaic power supply is presented as the most economic option. In addition, many developing countries have high radiation levels year round (NREL, 2009). 
Photovoltaic systems cause few environmental problems commonly related to their manufacturing. The generating component produces electricity silently and does not emit any harmful gas during operation. The basic photovoltaic material for most common modules made out of silicon is entirely benign, and is available in abundance (NREL, 2009).

One criticism of early PV modules was that they consumed more energy during their production than they generated during their lifetime. With modern production methods and improved operational efficiencies this allegation is no longer true (NREL, 2009).

Many authors have been studied technologies involved into manufacturing of solar panels, specifically solar collectors, their applications, costs minimisation, conversion optimisation etc. (Barker, Jr. and Power, 1979; Reindl et al., 1990a; Reindl et al., 1990b; McCormick and Suehrcke, 1991; Al-Nimr and Alkam, 1998; Al-Nimr et al., 1998; Alkam and Al-Nimr, 1999).

The exact energy payback is directly dependent on the available solar resource and on the degree to which the system is operational. High levels of solar irradiation and a high utilization factor will offer more rapid energy paybacks than if there is less sun and less usage, but typically energy payback will be realized within three to four years (NREL, 2009).

Besides, in the economic remarks relative to the using of energetic sources, the caused environmental damages are not considered. If that was done, the energy produced by photovoltaic, and also the energy produced by others renewable sources, would conquest more competitiveness in confrontation with the traditional non renewable sources (NREL, 2009).

In example, applications in which photovoltaic technologies can be used are related following.

Agriculture:

- $\quad$ water pumping, irrigation;

- electric fencing for livestock and range management.

Community:

- water pumping, desalination and purification systems;

- lighting for schools and other community buildings.

Domestic:

- lighting, enabling studying, reading, income-producing activities and general increase in living standards;

- TV, radio, and other small appliances;

- water pumping.

Healthcare:

- $\quad$ lighting forwards, operating theatre and staff quarters;

- medical equipment;

- refrigeration for vaccines;

- communications (telephone, radio communications systems);

- water pumping;
- $\quad$ security lighting.

Small enterprises:

- lighting systems, to extend business hours and increase productivity;

- $\quad$ power for small equipment, such as sewing machines, freezers, grain grinders, battery charging;

- lighting and radio in restaurants, stores and other facilities.

Photovoltaic systems create no emission in the electricity generation. Avoided emissions are a very positive aspect. In a study made by Kroposki and De Blasio (2000) is resulted that a $10 \mathrm{~kW}$ photovoltaic system in Colorado (USA) avoids $10,105 \mathrm{~kg}$ in $\mathrm{CO}_{2}$ emissions and $1,801 \mathrm{~kg}$ in $\mathrm{NO}_{\mathrm{x}}$ emissions.

No pollution of the photovoltaic systems can be inserted in the economic analysis. The Denver Service Guideline estimated the costs associated with the production of carbon dioxide $\left(\mathrm{CO}_{2}\right)$ in $0.0088 \mathrm{US} \$ \mathrm{~kg}$, sulphur dioxide $\left(\mathrm{SO}_{2}\right)$ in $1.65 \mathrm{US} \$ / \mathrm{kg}$, and nitrogen oxides $\left(\mathrm{NO}_{\mathrm{x}}\right)$ in $7.48 \mathrm{US} \$ / \mathrm{kg}$ (Effert and Thompson, 2000).

The mean installation costs (including the devices) of photovoltaic systems were 5.7US $\$ / \mathrm{Wp}$ for grid connected systems and 13.9US $\$ / \mathrm{Wp}$ for standalone system in USA (Mortensen, 2001). These costs make high also the cost of electricity generated by photovoltaic plant.

The panels' costs influence considerably the final installation cost, from $40 \%$ to $75 \%$ (Delahoy and Kiss, 2000). The photovoltaic energetic source will be viable when the panels cost will be decreased, as is the perspective.

Hybrid options based on sustainable resources, mainly photovoltaic, have been studied as solution for small rural villages' energy demand, such as (Chendo and Salawu, 1989; Dhere, 1989; Bailey et al., 1991; Song, 1994; Leitch and Van Der Linde, 1995; De Groot, 1997; Harford, 1998; Valente and Almeida, 1998), also connection to grid and its control (Lamas et al., 2008).

\section{METHODOLOGY}

The study presents the software SOLAR 1.1 developed with purpose of helping the choice of photovoltaic panels available commercially including electric needs calculation for the installation applied to a case study for a school placed at Umbertide, near Perugia, Italy.

This new version of program help also to conduce the economic analysis for grid connected or standalone photovoltaic systems for the choice of convenient values of investment rate and annuity factor and it calculates the payback period of investment in the photovoltaic plant.

For these evaluations, exergoeconomic modelling were used, such as reported in Annex 1. 


\section{PROJECT OF PHOTOVOLTAIC SYSTEM FOR SUPPLYING A SCHOOL}

In this item, it will be shown a project made by the software SOLAR 1.1 for supplying a part of the electric demand of a school placed in Umbertide.

In this school a photovoltaic system is already existent, so the object of this paper is to compare the existent system with the project resultant from SOLAR 1.1 with intention to validate it.

The photovoltaic plant of this school is one of the research activity of the Department of Industrial Engineering at University of Perugia.

\section{Description of the Existent PV Plant}

In the school were implanted 220 photovoltaic panels PL 800 in multicrystalline silicon, connected in groups of 10 to form 22 arrays. Each array is connected to an inverter that transforms the direct current in alternating current, producing a voltage of $220 \mathrm{~V}_{\mathrm{AC}}$, as it is needed to supply the loads and to send the electricity into the grid.

The total surface of the photovoltaic field is $169.4 \mathrm{~m}^{2}$ and the nominal power of the plant is $15,400 \mathrm{Wp}$. Other panels characteristics are shown in the Table 1.

Table 1. Panels characteristics.

\begin{tabular}{|c|c|}
\hline \multirow{2}{*}{$\begin{array}{l}\text { Model } \\
\text { Type }\end{array}$} & PL 800 \\
\hline & $\begin{array}{l}\text { Multicrystalline } \\
\text { silicon }\end{array}$ \\
\hline Length & $1,220 \mathrm{~mm}$ \\
\hline Width & $555 \mathrm{~mm}$ \\
\hline Surface & $0.68 \mathrm{~m}^{2}$ \\
\hline Weight & $8 \mathrm{~kg}$ \\
\hline Peak power & $70 \mathrm{~W}_{\mathrm{p}}$ \\
\hline $\begin{array}{l}\text { Voltage of } \\
\text { power }\end{array}$ & $17.2 \mathrm{~V}$ \\
\hline $\begin{array}{l}\text { Current of maximum } \\
\text { power }\end{array}$ & $4 \mathrm{~A}$ \\
\hline Open circuit voltage & $21.3 \mathrm{~V}$ \\
\hline Short circuit current & $4.4 \mathrm{~A}$ \\
\hline
\end{tabular}

The system is grid connected, it was stipulated a contract with the electricity concessionary ENEL, in which is approved that the surplus of energy production is send into the grid and paid by ENEL at the same price of the sold electricity. This can be do until the energy produced by photovoltaic system is minor or equal to the energy bought from the grid, so the school cannot receive a monetary recompense by ENEL, but only a reduction of the payment till its resetting (ENEL, 2011).

This contract secures that the surplus of produced energy did not waste but it was sold to ENEL. It specially happens in summer, when the school is close, so the electricity consumption is low and the production is high for the major value of insolation. The contract secures also that the school can consume electricity from the grid when the electricity produced is lower than the demand.

The energy produced by the photovoltaic plant is about $17,000 \mathrm{kWh}$ in a year, the energy consumed by the school is about $45,000 \mathrm{kWh}$ in a year, so meanly, during the year, the condition of a photovoltaic production minor than the consumptions is respected.

\section{Project of Photovoltaic Plant by SOLAR 1.1}

To project a photovoltaic plant through SOLAR 1.1 , the values of latitude, annual mean cloudiness, and demand energy are required. The value of latitude of Umbertide is $43^{\circ} 18^{\prime} 25^{\prime \prime}$. The value of the annual mean cloudiness can be taken from meteorological tables, this value results equal to 5.4 tenths of overcast sky (Barra, 1981).

Inserting these values, the software draws the curve of daily insolation shown in Fig. 2.

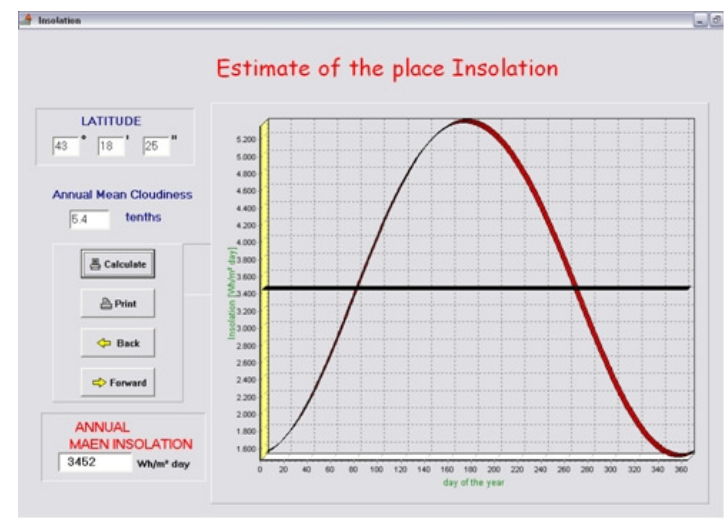

Figure 2. Estimate of the place insolation.

The annual mean insolation results equal to $3,452 \mathrm{Wh} / \mathrm{m}^{2}$.day for Umbertide region.

The Fig. 3 shows the window for insertion of energy values to calculate the peak power. In this case the value of peak power for this plant is known, it can be taken equal to the value of the existent photovoltaic plant that has a nominal peak power of $15,400 \mathrm{Wp}$. 


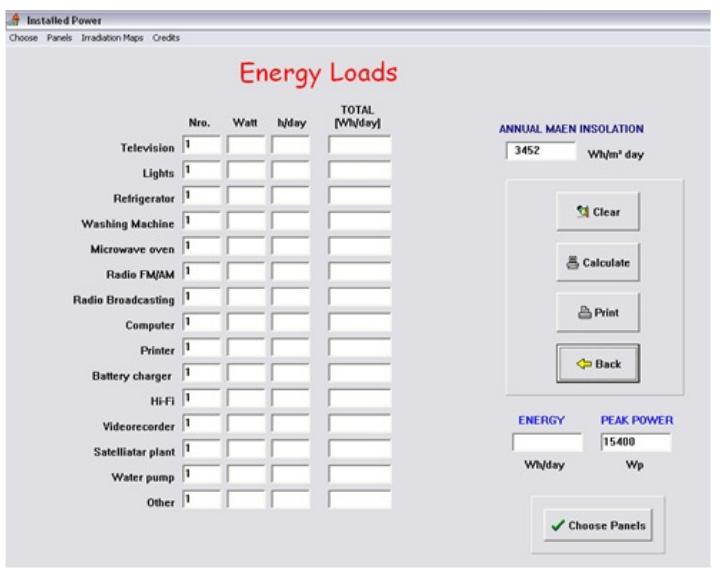

Figure 3. Peak power of the photovoltaic plant.

Now, it is possible to click the button Choose Panels to start the choice of the panels.

The panels chosen are shown in Fig. 4.

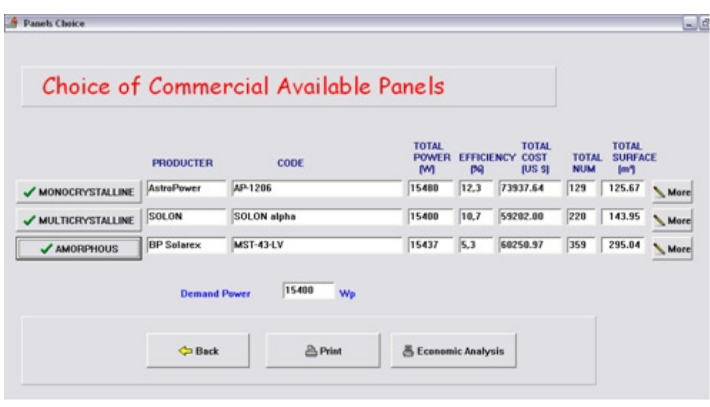

Figure 4. Panels chosen.

In the economic analysis, to make this project similar to the existent plant, it is taken the multicrystalline panels, model Solon Alpha and the grid connected system. Also, the multicrystalline panel have a cost lower than the monocrystalline and the amorphous ones (Fig. 4).

The panels Solon Alpha required in the plant are 220 and occupy an area of $143.5 \mathrm{~m}^{2}$.

Other characteristics of these panels are shown in the Fig. 5.

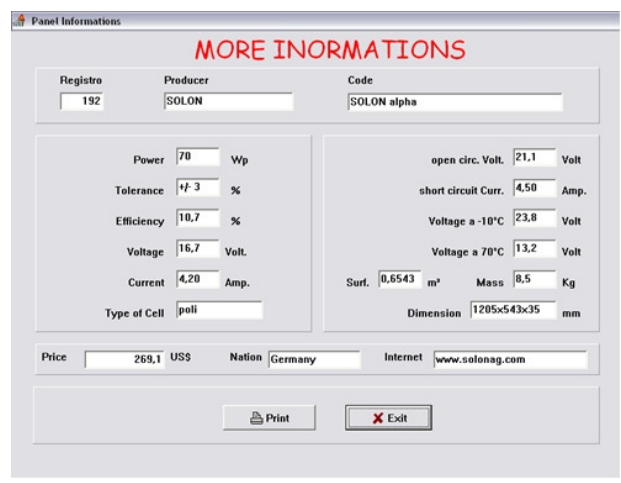

Figure 5. Panel Solon Alpha.
As it can be seen by confronting the Table 2 and the Fig. 5, the characteristics values of the panels in the existent plant and panels chosen by SOLAR 1.1 are similar.

For the economic analysis of a photovoltaic system implantation connected to grid, it can be considered an electricity price around $0.18 \mathrm{US} \$ / \mathrm{kWh}$ and a governmental subsidy rate of $75 \%$ into the investment cost.

The maximum value of subsidy that can be gave for photovoltaic plant with a nominal power from $1 \mathrm{~kW}_{\mathrm{p}}$ to $20 \mathrm{~kW}_{\mathrm{p}}$ is $75 \%$, connected to the electric grid, as it is instituted by a program of Ministero dell'Ambiente e della Tutela del Territorio in the law of March 16th, 2001.

The results of calculation of costs operated by the software are shown in the Fig. 6.

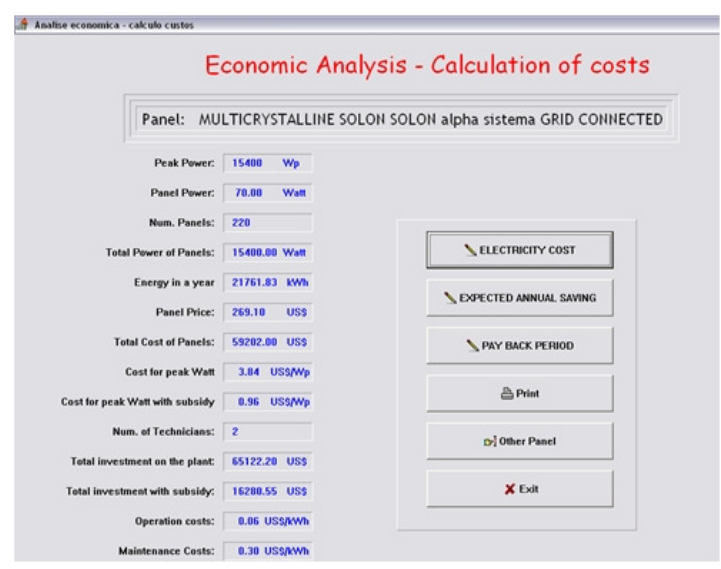

Figure 6. Calculation of costs.

Among the results, there is the energy producing during a year that, with these panels, is about $21,700 \mathrm{kWh}$. This value is higher than the value of $17,000 \mathrm{kWh}$ produced in a year by the existent plant. The cause of the difference is different values of panels' efficiency for: PL 800 is $6.97 \%$; and Solon Alpha is $10.7 \%$.

In Fig. 7 is shown the trend of electricity cost in the photovoltaic production in function of the amortisation period for different values of interest rate and in the situation of null subsidy and with subsidy of $75 \%$. 


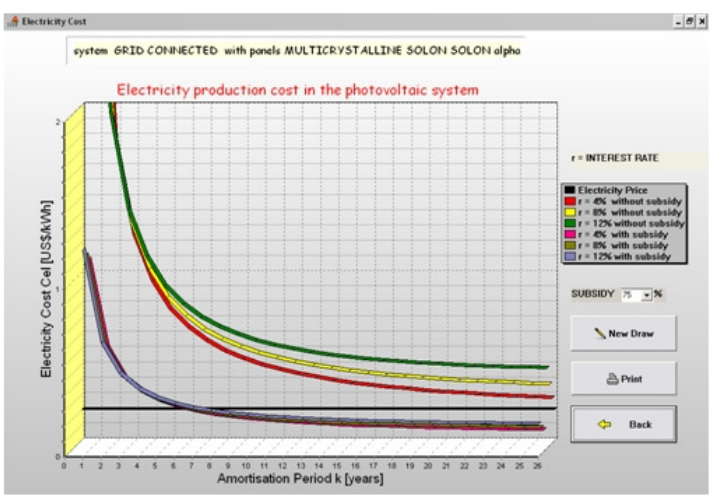

Figure 7. Electricity cost in photovoltaic production.

In this diagram it is possible to see that when the subsidy is null, the electricity cost is always higher than the grid electricity cost. When the subsidy is $75 \%$, the electricity cost becomes lower than the grid electricity cost.

The values of the amortisation period, for which the electricity cost in the photovoltaic production is equal to the electricity cost bought from the grid are shown in the zoom of diagram (Fig. 8).

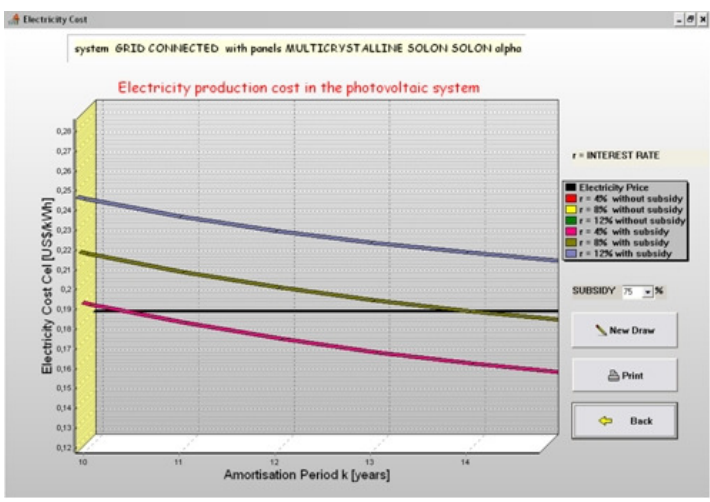

Figure 8. Zoom of electricity cost diagram.

These values are: 11 years for interest rate of $4 \%$; and 16 years for interest rate of $8 \%$.

It is evident that in case of absence of the subsidy rate, the photovoltaic plant is not convenient by economic view because the cost of electricity that is generated by the plant is higher than the electricity of the grid. So there is not benefit in consuming a electricity produced with a major cost and there is a loss in selling the electricity to the grid with a cost lower than the cost spend in the generation.

In other way, in case of subsidy rate, the cost of the electricity produced in photovoltaic system is lower than the grid electricity price so, selling the electricity to the grid there is a profit.

In the Fig. 9 is shown the diagram of the trend of the expected annual saving.

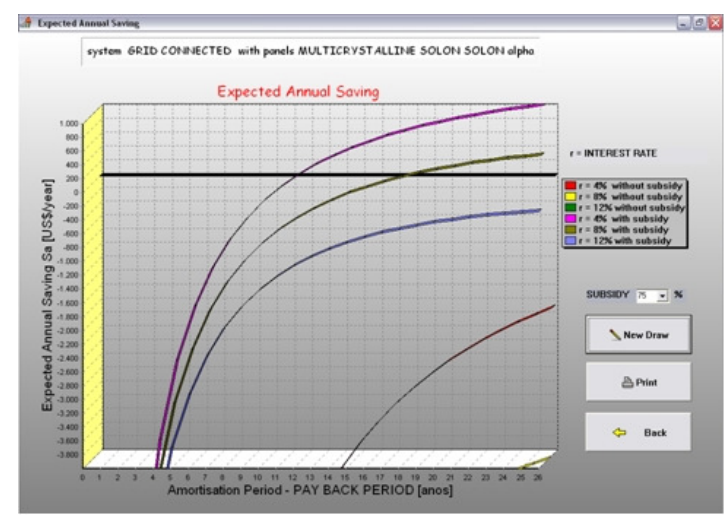

Figure 9. Expected annual saving.

In this diagram it can see that the plant produces economic benefit only in case of subsidy and the payback period of the investment is 11 years if the interest rate is $4 \%$ or 16 years if it is $8 \%$ (Figs. 10 and 11).

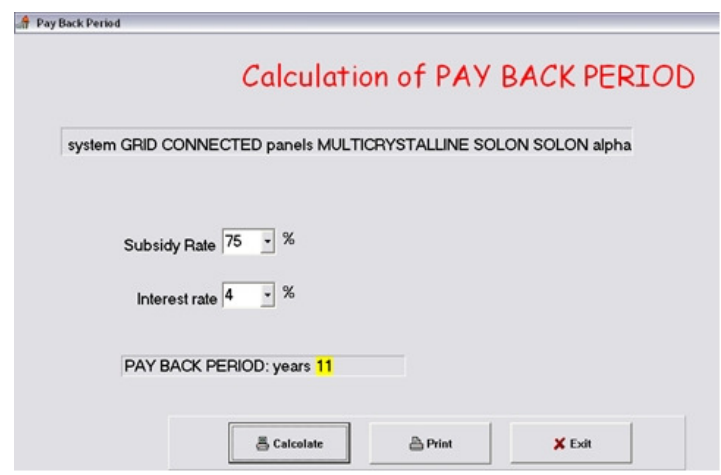

Figure 10. Payback with interest rate of $4 \%$.

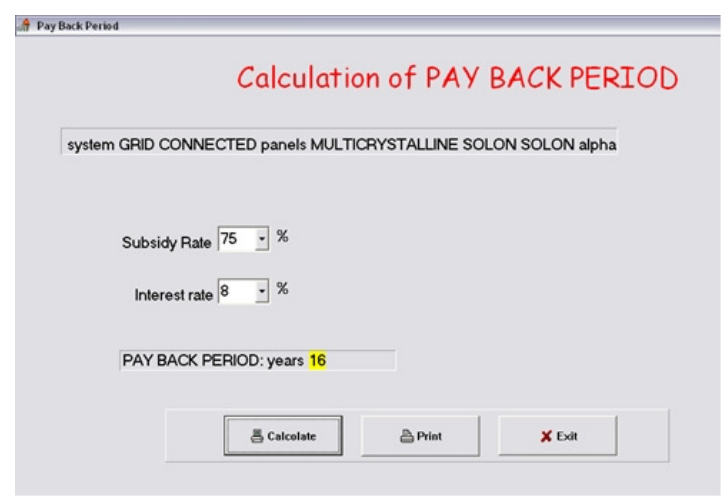

Figure 11. Payback with interest rate of $8 \%$.

\section{CONCLUSIONS}

The photovoltaic systems can be a good alternative source to satisfy energetic problem for the low environmental impact deriving by their utilisation. But they result not completely competitive 
in the economic confrontations with others energy sources for their high costs of implantation.

The benefits and the observations about using of photovoltaic is reassumed in the following:

Energetic:

- the stand alone PV systems offer the possibility to have electric energy in remote place where the electric grid is inexistent and then there is no convenience to install it;

- the grid connected PV systems can be located at both residential and commercial locations, they can be used to reduce peak demand when its output is properly matched with load usage.

Environmental:

- photovoltaic energy is a clean renewable resource. The fuel supply for these systems although variable is also free and unending;

- photovoltaic systems create no emission in the electricity production. Avoided emissions is a very positive aspect. In a study made by Kroposki and De Blasio (2000) is resulted that a $10 \mathrm{~kW}$ PV system in Colorado avoids $10,105 \mathrm{~kg}$ in $\mathrm{CO}_{2}$ emissions and $1,801 \mathrm{~kg}$ in $\mathrm{NO}_{\mathrm{x}}$ emissions.

Economic:

- the mean installation costs (including the devices) of photovoltaic systems in 2000 were 5.7US $\$ / \mathrm{W}_{\mathrm{p}}$ for grid connected systems and $13.9 \mathrm{US} \$ / \mathrm{W}_{\mathrm{p}}$ for standalone system in USA (Mortensen, 2001). These high costs make high also the cost of the electricity produced by the photovoltaic plant;

- the panels costs influence much the final installation cost, from $40 \%$ to $75 \%$ (Delahoy and Kiss, 2000). The PV energetic source will be very alternative when the panels cost will be decreased, as is the perspective;

- $\quad$ in the case studied in this work was seen as in situation in which the electric tariff is low, as in the Brazilian condition (electricity price is $0.08 \mathrm{US} \$ / \mathrm{kWh}$ ), the PV energy can be competitive only if the government incentives the installation with subsidy;

- no pollution of the PV systems can be inserted in the economic analysis. The Denver Service Guideline estimated the costs associated with the production of carbon dioxide $\left(\mathrm{CO}_{2}\right)$ in $0.0088 \mathrm{US} \$ / \mathrm{kg}$, of sulphur dioxide $\left(\mathrm{SO}_{2}\right)$ in $1.65 \mathrm{US} \$ / \mathrm{kg}$, and of nitrogen oxides $\left(\mathrm{NO}_{\mathrm{x}}\right)$ in $7.48 \mathrm{US} \$ / \mathrm{kg}$ (Effert and Thompson, 2000).

If the environmental benefits due to the no emissions of polluting substances was considered in the economic analysis, the economic benefit would be $13,000 \mathrm{US} \$$ /year only for the absence of emitted $\mathrm{NO}_{\mathrm{x}}$ in a $10 \mathrm{~kW}_{\mathrm{p}}$ plant, as it results by combining the environmental studies of Kroposki and De Blasio (2000) and the economic studies of the Denver Service Guideline.
The objective of this work was the development of a new version of the software Solar in which is contained the instruments to conduce the economic analysis of PV system.

The software can be update in future with the introduction of new archives for the selection of the devices necessary for the plant. So, it will can be inserted an archive with the models of batteries and one with the models of inverters.

In the software can also be inserted a function that considers the benefit of the no emission in the economic analysis.

Another upgrade that can be done is a technical function that premise to operate the calculation relative to the modules connection. Knowing the values of wanted power, voltage and current, through this function it is possible to find the number of the modules branch in parallel and the number of modules connected in series in each branch.

In conclusion, it can be told that with the subsidy rate, the high cost of the technologies in photovoltaic production can be reduced. This decrease does become the photovoltaic an energy source economically competitive with traditional energy sources.

\section{REFERENCES}

Alkam, M. and Al-Nimr, M. A., 1999, Solar Collector with Tubes Partially Filled with Porous Substrate, ASME Journal of Solar Energy Engineering, Vol. 121, pp. 20-24.

Al-Nimr, M. A. and Alkam, M., 1998, A Modified Tubeless Solar Collector Partially Filled with Porous Substrate, Renewable Energy, Vol. 13, No. 2, pp. 165-173.

Al-Nimr, M. A., Kiwan, S., and Al-Alwah, A., 1998, Size Optimization of Conventional Solar Collectors, Energy - The International Journal, Vol. 23, No. 5, pp. 373-378.

Bailey, B., Perez, R., Doty, J., Elsholz, K., Stewart, R., and Huse, W., 1991, Early Experiences of the $15 \mathrm{~kW}$ NMPC Demand-side Management Photovoltaic Project, Solar Cells, Vol. 30, No. 1-4, pp. 529-533.

Barker, Jr., A. S. and Power, H. J., 1979, Photovoltaic Solar Cell Array Used for Supplemental Power Generation, Solar Energy, Vol. 23, No. 5, pp. 427-434.

Barra, O. A., 1981, The Photothermal Conversion of Solar Energy: Design and Research of Plants and Solar Systems, Etas Libri. [in Italian]

Chendo, M. A. C. and Salawu, R. I., 1989, Design Considerations of a Total Energy Power System for a Rural Health Centre in Nigeria, Solar \& Wind Technology, Vol. 6, No. 6, pp. 747-754.

De Groot, P., 1997, A Photovoltaic Project in Rural Africa: A Case Study, Renewable Energy, Vol. 10, No. 2-3, pp. 163-168. 
Delahoy, A. E. and Kiss, Z. J., 2000, Photovoltaics: Heading Towards Thin Film, Energy Photovoltaic, Inc.

Dhere, N. G., 1989, The Development of Solar Photovoltaic Energy in Brazil, Solar Cells, Vol. 26, No. 1-2, pp. 13-23.

Effert, P. and Thompson, A., 2000, U.S. Guidelines the Economic Analysis of Buildingintegrated Photovoltaic Power Systems, NREL National Renewable Energy Laboratory, TP 71025266.

Enel Group. Solar Power - Technology. 2011. [online]. Enel SpA. Available at: $<$ http://www.enel.com/en-

GB/innovation/project_technology/renewables_devel opment/solar_power/>.

Harford, J. R. J., 1998, BP Solar and Photovoltaic Projects: A Case Study Health Centre Rehabilitation Project in Zambia, Renewable Energy, Vol. 15, No. 1-4, pp. 491-495.

Kroposki, B. E. and De Blasio, R., 2000, Technologies for the New Millennium: Photovoltaics as a Distributed Resource, in: NREL - National Renewable Energy Laboratory, IEEE Power Engineering Society (PES), Seattle, Washington, July 16-20.

Lamas, W. Q., Tani, H. M., Reis, L. O. M., and Ribeiro, A. C., 2008, Fuzzy Logic Control Applied to a Photovoltaic System Connected to City Network for Residential Use, Engenharia Térmica (Thermal Engineering), Vol. 7, No. 2, pp. 21-26.

Leitch, A. W. R. and Van Der Linde, H. A., 1995, A Photovoltaic Project for the Rural Areas of the Eastern Cape, South Africa, Renewable Energy, Vol. 6, No. 5-6, pp. 549-551.

McCormick, P. G. and Suehrcke, H., 1991, Diffuse Fraction Correlations, Solar Energy, Vol. 47, No. 4, pp. 311-312.

Mortensen, J., 2001, Factors Associated with Photovoltaic System Cost, NREL - National Renewable Energy Laboratory, TP 620-29649.

National Renewable Energy Laboratory (USA), 2009, Solar Research, National Renewable Energy Laboratory.

Reindl, D. T., Beckman, W. A., and Duffie, J. A., 1990a, Diffuse Fraction Correlations, Solar Energy, Vol. 45, No. 1, pp. 1-7.

Reindl, D. T., Beckman, W. A., and Duffie, J. A., 1990b, Evaluation of Hourly Tilted Surface Radiation Models, Solar Energy, Vol. 45, No. 1, pp. 9-17.

Song, J., 1994, Recent Progress in National Photovoltaic Project in Korea, Solar Energy Materials and Solar Cells, Vol. 34, No. 1-4, pp. 5156.

Valente, L. C. G. and Almeida, S. C. A., 1998, Economic Analysis of a Diesel-photovoltaic Hybrid System for Decentralized Power in Northern Brazil, Energy Journal, Vol. 23, No. 4, pp. 317-23.

\section{ANNEX 1}

Electric Energy Production Cost

$$
C_{e l}=\frac{I_{p l} \times\left(1-\frac{S_{u b}}{100}\right)}{E_{p}} \times f+C_{o p}+C_{m a}
$$

\section{Annuity Factor}

$f=\frac{q^{k} \times(q-1)}{q^{k}-1}$

$q=1+\frac{r}{100}$

\section{Energy Produced}

$$
E_{p}=\frac{\eta_{M}}{100} \times R_{A} \times A
$$

\section{Total Investment Cost}

$I_{p l}=C_{m} \times n_{m}+C_{d}+C_{b}$

\section{Operation Costs}

$C_{o p}=\frac{n_{t e c} \times S_{a l} \times n_{m}}{E_{p}}$

\section{Expected Annual Saving}

$$
S_{e}=E_{p} \times\left(P_{e l}-C_{e l}\right)
$$

Expected Annual Saving for Standalone System

$S_{e}=E_{p} \times\left(C_{m_{e x}}-C_{e l}\right)$

Daily Demand Energy

$E=\sum_{i=1}^{k} n_{i} \times P_{i} \times H_{i}$

\section{Nominal Plant Power (Peak Power)}

$P_{p}=\frac{E \times 1,000}{0.9 \times R}$

In Eq. (A10), “1,000” is a standard value of irradiance, in $\mathrm{W} / \mathrm{m}^{2}$.

\section{Energy Produced in a Year}


$E_{P}=R_{A} \times A \times \frac{\eta}{100}$

Annual Insolation

$R_{A}=\int_{0}^{365} R d t$

Cost of Panel in Function of the Nominal Power for: Monocrystalline Panels, Eq. (A13); Multicrystalline Panels, Eq. (A14); and Amorphous Panels, Eq. (A15)

$C_{m}=182.322875 \times 1.013406^{P_{p}}$

$C_{m}=306.118327 \times 1.008568^{P_{p}}$

$\log \left(C_{m}\right)=0.0180791 \times P_{p}+4.73025$

Received: June 09, 2009

Revised: July 09, 2009

Accepted: August 09, 2009 